\author{
ANDRZEJ WegGiel ${ }^{1}$, PAUlina NOWACZYK ${ }^{2}$, ANGELIKA ŚMidOWicZ ${ }^{2}$, \\ BLANKA WIATROWSKA ${ }^{3}$
}

${ }^{1}$ Katedra Urzadzania Lasu

${ }^{2}$ Katedra Higieny Żywienia Człowieka

${ }^{3}$ Katedra Botaniki Leśnej

Uniwersytet Przyrodniczy w Poznaniu

Wojska Polskiego 28, 60-637 Poznań

E-mail:wegiel@up.poznan.pl

\title{
WŁAŚCIWOŚCI OLEJU PALMOWEGO I WPŁYW PLANTACJI OLEJOWCA GWINEJSKIEGO (ELAEIS GUINEENSIS JACQ.) NA ŚRODOWISKO
}

\section{WSTEP}

Olej palmowy powszechnie wykorzystywany jest w przemyśle spożywczym, kosmetycznym i energetycznym. Jest on składnikiem wielu produktów żywnościowych, takich jak: margaryna, wyroby mleczne, czekolada, chipsy, batony, pieczywo, zupy instant, sosy czy dania gotowe. Zwłaszcza na terenach Azji Południowo-Wschodniej, powszechnie stosuje się go do smażenia. Wchodzi on także w skład wielu kosmetyków i środków czystości oraz biopaliw i olejów silnikowych.

Olej ten pozyskiwany jest $z$ owoców olejowca gwinejskiego (Elaeis guineensis Jacq.), zwanego popularnie palma olejową. Plantacje tej rośliny zajmuja ogromne obszary strefy tropikalnej, głównie w Azji Południowo-Wschodniej. Coraz częściej zwraca się uwage na fakt, że wielka skala tej produkcji może wywołać poważne konsekwencje środowiskowe. Zakładanie plantacji olejowca gwinejskiego powoduje bowiem wycinanie ogromnych połaci lasów, osuszanie mokradeł, wzrost emisji dwutlenku węgla oraz zwiększenie ryzyka wystapienia pożarów i powodzi. $Z$ drugiej strony, produkcja oleju palmowego stymuluje rozwój gospodarczy regionów, w których się go wytwarza. Jest też odpowiedzia na rosnące zapotrzebowanie na żywność i energię, związane ze wzrostem liczby ludności na świecie.

Niejednoznaczny pozostaje wpływ spożycia oleju palmowego na zdrowie człowieka. Pod powszechnie stosowana nazwa „olej pal- mowy" kryje się kilka różnych postaci tego produktu, o różnym stopniu przetworzenia i odmiennej wartości odżywczej. Problematyczny jest również fakt, że przeważajacca część spożywczego oleju palmowego, pochodzi $z$ tzw. produktów o wysokim stopniu przetworzenia. Wartość odżywcza takich produktów i ich wpływ na zdrowie jest wypadkowa działania wszystkich składników obecnych w produkcie, a dodatkowo może być modyfikowana sposobem ich przygotowania do spożycia.

\section{PLANTACJE OLEJOWCA GWINEJSKIEGO}

Olejowiec gwinejski jest palma pochodzaca $z$ Afryki, powszechnie uprawiana na plantacjach w całej strefie tropikalnej (Ryc. 1), zdecydowana większość jego plantacji znajduje się jednak w Azji Południowo-Wschodniej. Dwaj najwięksi producenci oleju palmowego to Indonezja i Malezja, którzy łacznie pokrywaja ponad $85 \%$ światowego zapotrzebowania na ten surowiec (GAVEAU i współaut. 2016).

Produkcja olejów roślinnych to obecnie najszybciej rozwijająca się gałą́ rolnictwa, a plantacje wytwarzajace olej palmowy, w porównaniu do upraw innych roślin oleistych, charakteryzuja się największa produkcyjnością. Ich wydajność wynosząca 4,2 tony/ ha/rok jest około czterokrotnie wyższa niż wydajność innych upraw roślin oleistych (Ryc. 2). Olej palmowy charakteryzuje się też 


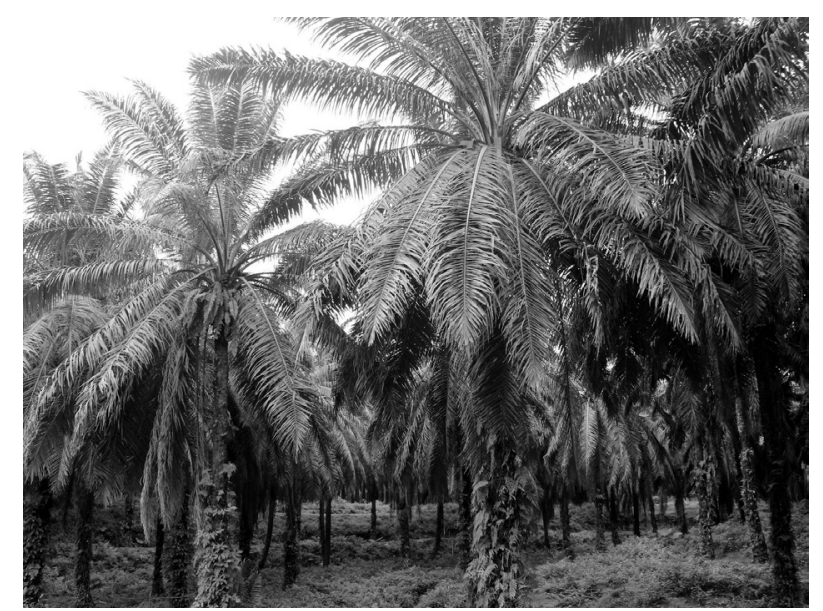

Ryc. 1. Plantacja olejowca gwinejskiego na Sumatrze (fot. A. Węgiel).

najniższymi kosztami produkcji (TAN i współaut. 2009), co powoduje, że obecnie jest on najczęściej wytwarzanym olejem roślinnym na świecie (EDWARDS i współaut. 2014).

Skala tego zjawiska stwarza wiele problemów środowiskowych i etycznych. Wśród problemów tych wymienia się m.in.: usuwanie wielkich połaci lasów deszczowych w strefie tropikalnej, osuszanie mokradel, negatywne oddziaływanie powstajacych przy jego produkcji ścieków na ekosystemy wodne i lądowe (AFRIYANTI i wspólaut. 2016), konflikty społeczne wynikajace $z$ praw zwiazanych $z$ własnościa gruntów czy ograniczanie dostępu lokalnej ludności do zasobów środowiska (SUMARGA i HEIN 2016).

Ważny jest także społeczno-gospodarczy aspekt tej działalności. Plantacje olejowca gwinejskiego sa bowiem ważnym elementem rozwoju wielu krajów położonych w strefie tropikalnej, a ich zakładanie sprzyja rozwojowi obszarów wiejskich i zapewnia pracę lokalnej ludności (AFRIYANTI i współaut. 2016). W miejscach, gdzie koszty pracy i gruntów sa stosunkowo niskie, a alternatywne możliwości zarobku sa ograniczone, plantacje przynosza istotne dochody dla ludności (GAVEAU i współaut. 2016). Z punktu widzenia rolników istotna jest także stosunkowo mała pracochłonność prowadzenia plantacji i brak sezonowości zbiorów (Tsujino i współaut. 2016).

\section{WYLESIANIE OBSZARÓW TROPIKALNYCH}

Zakładanie plantacji palmy olejowej uznaje się za główną przyczynę wylesień w Azji Południowo-Wschodniej (CARRASCO i współaut. 2014). Wzrost zapotrzebowania na olej palmowy prowadzi do rozwoju tej gałęzi rolnictwa, a ponieważ zasięg olejowca gwi-

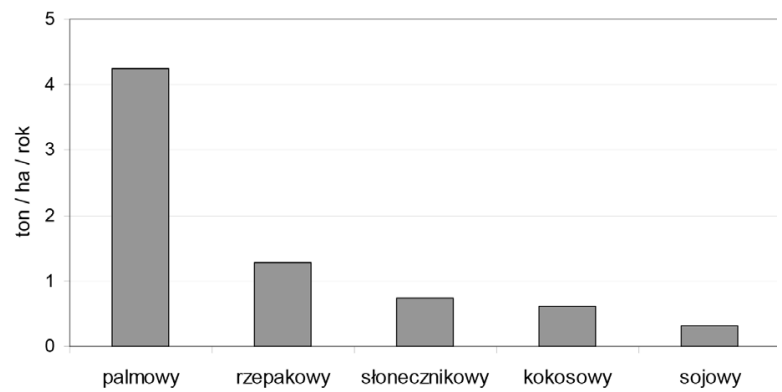

Ryc. 2. Wydajność upraw roślin oleistych: palmy olejowej, rzepaku, słonecznika, palmy kokosowej i soi; olej $\mathrm{w}$ tonach na ha na rok (na podstawie: TAN i współaut. 2009).

nejskiego ogranicza się do wilgotnych obszarów tropikalnych, najczęściej odbywa się to kosztem terenów zajmowanych przez okołorównikowe lasy deszczowe.

Zakładanie plantacji olejowca gwinejskiego wpływa na powstawanie wylesień m.in. poprzez (i) wykonywane zrębów w celu uzyskania miejsca pod plantacje, (ii) wyrab lasów dla uzyskania funduszy ze sprzedaży drewna na pokrycie kosztów założenia plantacji oraz pośrednio, (iii) poprzez budowę sieci dróg do wcześniej niedostępnych obszarów (FITZHERBERT i współaut. 2008).

Indonezja (największy producent oleju palmowego) na początku XX w. była prawie w całości pokryta lasem, jej lesistość wynosiła około 99\%. W wyniku prowadzonych od lat 70. intensywnych wylesień, jej lesistość spadła do 49,8\% w 2015 r. Z danych FAO wynika, że powierzchnia lasów w tym kraju zmniejszyła się z 118,5 $\mathrm{mln}$ ha w $1990 \mathrm{r}$. do $91,0 \mathrm{mln}$ ha w 2015 r. (TsuJino i współaut. 2016). Plantacje palmy olejowej zakładane były w tym kraju już od 1911 r., poczatkowo jednak bardzo mało intensywnie. W latach 2005-2011 tempo ich ekspansji wynosiło średnio 514 tys. ha na rok (Ryc. 3), przez co w 2010 r. zajmowały już 7,7 $\mathrm{mln}$ ha (SUMARGa i HeIN 2016).

Trudno jest dokładnie określić w jakim stopniu bezpośrednia przyczyna wylesień jest produkcja oleju palmowego. Niektóre tereny wylesiane sa $z$ innych powodów, a następnie przeznaczane na plantacje, co może być błędnie identyfikowane. Dane dotyczace użytkowania gruntu często nie pozwalaja jednoznacznie określić, w których miejscach lasy były wycinane na potrzeby założenia plantacji, a w których plantacje były zakładane na terenach wcześniej zdegradowanych przez pożary lub nielegalny wyrąb (FITZHERBERT i współaut. 2008). Jak zauważa TAN i współaut. (2009), rolnicy wola zakładać plantacje na terenach pokrytych lasem, by uzyskać przychód ze sprzedaży drewna i 


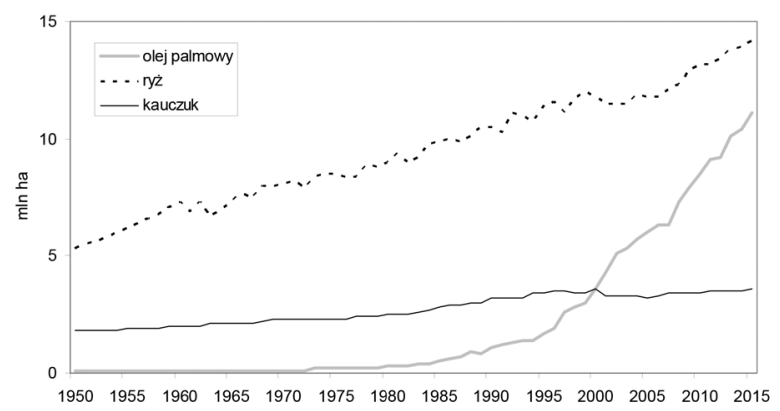

Lata

Ryc. 3. Zmiany powierzchni (w mln ha) upraw palmy olejowej, ryżu i kauczukowca w Indonezji w latach 1950-2015 (na podstawie: TsuJiNo i współaut. 2016).

przeznaczyć go na pokrycie kosztów nasadzeń. W Indonezji, ze względu na niejasny system własności, regionalną autonomię i powszechna korupcję, łatwiejsze jest bowiem uzyskanie koncesji na wyrab lasu pod plantacje niż na pozyskanie drewna. Znane sa więc przypadki porzucania zrębów wykonanych pod pretekstem zakładania plantacji (MUKHERJEe i SOVACOOL 2014).

\section{WPEYW PLANTACJI OLEJOWCA GWINEJSKIEGO NA RÓŻNORODNOŚĆ BIOLOGICZNA}

Aż 44\% wszystkich gatunków roślin naczyniowych i 35\% wszystkich gatunków kręgowców występuje na obszarze 25 centrów różnorodności biologicznej (tzw. „hot-spoty"), które zajmują zaledwie 1,4\% powierzchni Ziemi (MYERS i współaut. 2000). W Azji Południowo-Wschodniej wyróżniono 4 hot-spoty, o odmiennej historii geologicznej, charakteryzujące się bardzo duża liczba gatunków rzadkich i endemicznych (występujących tylko na tym obszarze). Jednym $z$ nich jest „SUNDALAND”, obejmujący swoim zasięgiem Malezję i większą część Indonezji, $\mathrm{w}$ tym m.in. Sumatrę, Borneo i Jawę (SoDHI i współaut. 2004). W obrębie hot-spotu „SUNDALAND” endemicznych jest ok. 35\% gatunków ssaków, 17\% ptaków, 62\% gadów, $79 \%$ płazów i 60\% gatunków roślin, z których wiele zwiazanych jest wyłacznie $z$ siedliskami leśnymi (SODHI i współaut. 2004).

Mimo że lasy Azji Południowo-Wschodniej sa jednymi $z$ najbogatszych ekosystemów lądowych (Ryc. 4), jednocześnie należą do najbardziej zagrożonych (LAURANCE 2007). W porównaniu $Z$ innymi regionami pokrytymi lasami tropikalnymi, Azja Południowo-Wschodnia charakteryzuje się największym wskaźnikiem wylesienia (ACHARD i współaut. 2002), co zwiazane jest $z$ masowa uprawa

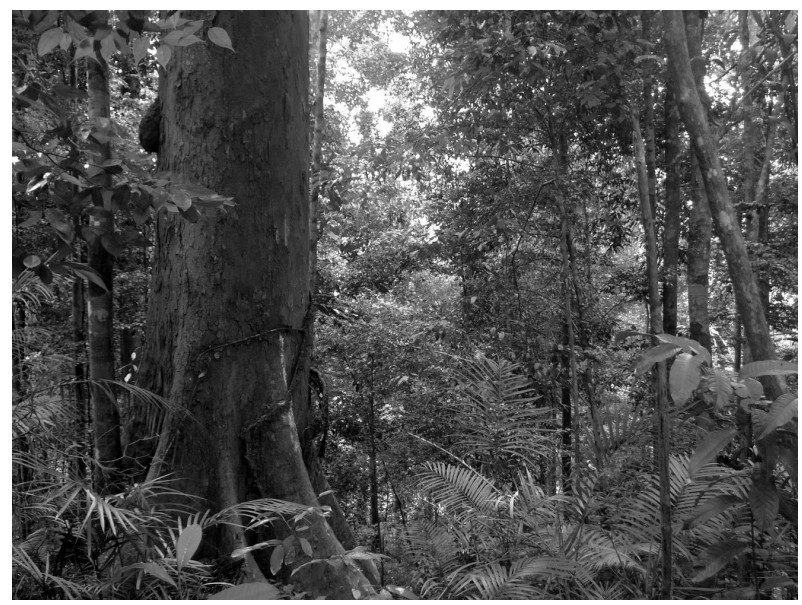

Ryc. 4. Naturalne lasy deszczowe cechuje bardzo wysoka różnorodność biologiczna - wilgotny las równikowy w Parku Narodowym Gunung Leuser na Sumatrze (fot. A. Węgiel).

olejowca gwinejskiego (FITZHERBERT i współaut. 2008, KOH i Wilcove 2008). Pomimo zauważalnego wpływu uprawy tej rośliny na różnorodność biologiczną (ARATRAKORN i współaut. 2006, SCHARLEMANN i LAURANCE 2008), brakuje pełnego oszacowania kosztów środowiskowych tej działalności (GROOM i współaut. 2008, TURNER i współaut. 2008). Dowiedziono jednak, że siedliska, na których założono plantacje sa silnie zniekształcone. W porównaniu $z$ naturalnym lasami maja one inny mikroklimat. Dobowa temperatura powietrza jest tam wyższa średnio o $2,8^{\circ} \mathrm{C}$, a wilgotność powietrza, wyrażona prężnościa pary wodnej, niższa (LUSKIN i POTTS 2011), co wraz $z$ innymi czynnikami wpływa na obniżenie różnorodność biologicznej tych terenów (FITZHERBERT i współaut. 2008, KOH i Wilcove 2008, DANIELSEN i współaut. 2009).

W porównaniu $z$ rozpowszechnionymi $w$ Azji Południowo-Wschodniej plantacjami innych gatunków drzew, na przykład kauczukowca (Hevea brasiliensis) czy akacji (Acacia mangium), na plantacjach olejowca stwierdzono najmniejsze podobieństwo gatunkowe występujących tam organizmów do zbiorowisk leśnych (FITZHERBERT i współaut. 2008). Plantacje wpływaja na coraz większa fragmentację naturalnych ekosystemów, co utrudnia migrację zwierząt (STRUEBIG i współaut. 2008), a poprzez zwiększenie długość krawędzi lasu, naraża istniejące ekosystemy na szkodliwe oddziaływanie efektu brzegowego (FISCHER i LINDENMAYER 2007).

Porównanie różnorodności biologicznej występujacych w Azji Południowo-Wschodniej lasów dwuskrzydlcowych i plantacji olejowca gwinejskiego, przeprowadzone na podstawie wyników wielu badań wykazało, że na plantacjach występuje 23\% gatunków kręgowców 
i 31\% gatunków bezkręgowców stwierdzanych w lasach. Oznacza to, że podobieństwo gatunkowe tych dwóch formacji wynosi $29 \%$ w przypadku kręgowców i $21 \%$ w przypadku bezkręgowców, zaś bogactwo gatunkowe kręgowców z plantacji, stanowi 38\%, a w przypadku bezkręgowców 89\%, całkowitego bogactwa naturalnych lasów (DANIELSEN i współaut. 2009). Jak wskazuje YUE i współaut. (2015) istnieje jednak duże prawdopodobieństwo, że jest ono przeszacowane.

Duże różnice w liczbie gatunków występujacych w naturalnych lasach i na plantacjach obserwowane sa zwłaszcza w przypadku ssaków, w szczególności zaś nietoperzy i ich dużych przedstawicieli. Na plantacjach olejowca stwierdzono ich odpowiednio 8 i 9,5 razy mniej niż w zbiorowiskach leśnych. Spośród 38 gatunków średnich i dużych ssaków żyjących w lasach Sumatry, na plantacjach zaobserwowano jedynie 4 (MADDOX i współaut. 2007). Na plantacjach olejowca gwinejskiego nie występuja rzadkie i zagrożone gatunki jak: słoń indyjski, tygrys sumatrzański czy pantera mglista (MADDOX i współaut. 2007, LUSKIN i współaut. 2014). Nie stwierdzono również gaurów, nosorożców sumatrzańskich (LUSKIN i współaut. 2014) czy orangutanów (Ryc. 5) (CAMPBELL-SMITH i współaut. 2011). Budowa liści olejowca, których ogonki gęsto pokryte sa kolczastymi wyrostkami, uniemożliwia bowiem przemieszczenie się tych małp pomiędzy pióropuszami palm. Na plantacjach bardzo wyraźnie zaznacza się natomiast rozrost populacji dzików, dla których obficie owocujące przez cały rok palmy stanowia stałe i bogate źródło pokarmu (ICKES 2001). Bardzo rozpowszechnione sa tam także szczury, których liczebność może dochodzić do 600 osobników na hektar (WOOD i FEE 2003).

$\mathrm{Na}$ plantacjach olejowca zdecydowanie mniejsza jest różnorodność gatunkowa ptaków, których stwierdzono prawie trzykrotnie mniej niż w zbiorowiskach leśnych (ARATRAKORN i współaut. 2006). Jak oblicza EDWARDS i współaut. (2010), dwustukrotnie mniejsza jest także liczebność tych gatunków awifauny, które według Birdlife International (www.birdlife.org) sa najbardziej zagrożone. Zbliżone jest natomiast bogactwo gatunkowe płazów bezogonowych. Jednak, jak stwierdza FARUK i współaut. (2013), istotne różni się ich struktura gatunkowa, ponieważ na plantacjach występuja przede wszystkim gatunki typowe dla siedlisk zaburzonych. Niska wilgotność i duża dobowa amplituda temperatury na tych obszarach (LUSKIN i POTTS 2011) negatywnie wpływaja bowiem na wiele gatunków zmiennocieplnych płazów (GALlMETZER i Schulze 2015).

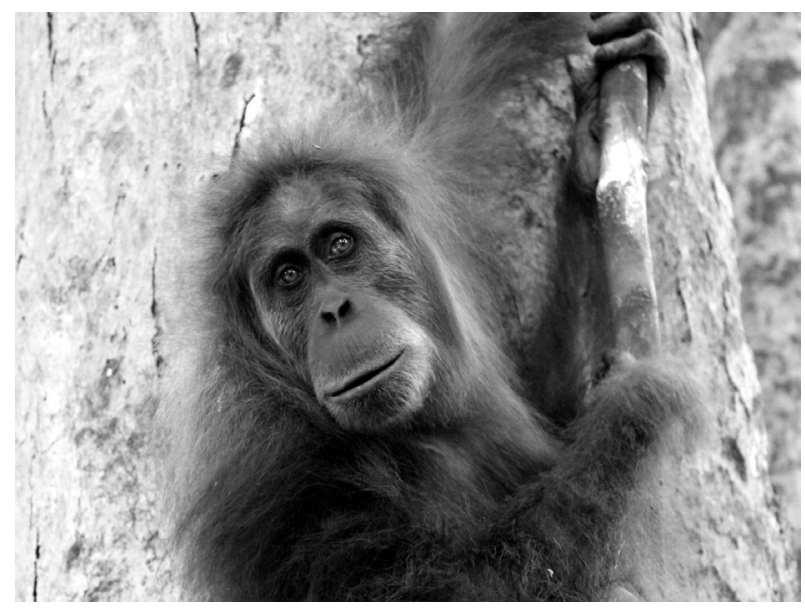

Ryc. 5. Orangutan sumatrzański - krytycznie zagrożony endemit Sumatry (fot. A. Węgiel).

Wśród zbadanych rzędów owadów na plantacjach mniej liczne sa motyle $(\mathrm{KOH}$ 2008) oraz podziemne i naziemne chrzasscze, których jest tam od 4 do 7 razy mniej (Chung i współaut. 2000). Istnieja również takie grupy systematyczne, których różnorodność na powierzchniach leśnych i plantacjach jest podobna, a nawet wykazuja większe liczebności na siedliskach silnie zniekształconych. Należą do nich m.in. niektóre gatunki mrówek, pszczół czy ciem (DANIELSEN i współaut. 2009). Liczne i różnorodne sa np. gildie mrówek żyjacych na pniach olejowca, wśród epifitycznych paproci (FAYLE i współaut. 2010). Jak zauważa PFEIFFER i współaut. (2008), aż 40\% gatunków mrówek występujących na plantacjach olejowca w Malezji to jednak gatunki obce, $\mathrm{w}$ tym m.in. pochodzaca prawdopodobnie $z$ Afryki (HolWAY i współaut. 2002), bardzo inwazyjna, żółta szalona mrówka (Anoplolepis gracilipes), która negatywnie wpływa na inne owady i pajęczaki (BRÜHL i ELTZ 2010).

Słabo zbadana jest natomiast flora plantacji olejowca gwinejskiego (DoNALD 2004). W porównaniu do naturalnych zbiorowisk leśnych jest ona jednak zdecydowanie uboższa. Na plantacjach nie występuja drzewiaste gatunki leśne i inne typowe dla lasów deszczowych gatunki palm, lian czy epifitycznych storczyków (DANIELSEN i współaut. 2009). Wyraźnie zaznacza się natomiast duża liczebność paprotników, których bogactwo gatunkowe na plantacjach bywa wyższe niż w naturalnych zbiorowiskach leśnych. Paprotniki dominujace na plantacjach, stanowia jednak głównie gatunki nieleśne i ruderalne, występujące głównie na siedliskach zaburzonych, np. wzdłuż dróg czy na pożarzyskach, w zbiorowiskach we wczesnych fazach sukcesji. Nie rosna tam natomiast gatunki cieniolubne, będace typowymi skład- 
nikami runa lasów deszczowych (DANIELSEN i współaut. 2009). Jako że różnorodność gatunkowa grzybów i roślin jest ściśle związana, utrata bogactwa gatunkowego roślin skutkuje również zmniejszeniem różnorodności grzybów (Tsui i współaut. 1998).

Podsumowując można stwierdzić, że przekształcenie naturalnych zbiorowisk lesnych w plantacje palmy olejowej powoduje znaczne zubożenia różnorodności biologicznej. Często plantacje zdominowane sa przez kilka gatunków ekspansywnych (FITZHERBERT i współaut. 2008). W silnie uproszczonych formacjach roślinnych, rzadkie, stenotopowe i wyspecjalizowane pokarmowo gatunki leśne, jak np. organizmy żyjące w dziuplach dużych drzew (FITZHERBERT i współaut. 2008), zastępowane sa przez rozpowszechnione gatunki nieleśne, o szerokiej skali ekologicznej (DANIELSEN i współaut. 2009). Te silnie zniekształcone zbiorowiska oraz sasiadujace $z$ nimi ekosystemy leśne podatne sa również na dalszą degradację zwiąana m.in. $z$ rozprzestrzenianiem się gatunków obcych i inwazyjnych.

Jako że olejowiec gwinejski ma kluczowe znaczenie dla gospodarki Azji Południowo-Wschodniej (BASIRON 2007), podejmowane są próby wypracowania bardziej zrównoważonych metod produkcji oleju palmowego, które nie skutkowałyby tak drastyczna utrata różnorodności biologicznej (LUCEY i HILL 2012). Jak dowodza badania, niewiele jest jednak możliwości zagospodarowania plantacji w taki sposób, by stały się bardziej przyjazne dla zwierząt (EDWARDS i współaut. 2010, Yue i współaut. 2015). Przyszła ekspansja plantacji powinna ograniczać się do już istniejacych terenów uprawnych lub zdegradowanych (KOH i WILCOVE 2008). Konieczne jest też wprowadzenie kompleksowych rozwiazań systemowych skierowanych do przetwórców i konsumentów, które promowałyby bardziej ekologiczny model uprawy palmy olejowej (WILCOVE i KOH 2010).

\section{CERTYFIKACJA PRODUKCJI OLEJU PALMOWEGO}

Plantacje olejowca gwinejskiego moga być zakładane na terenach leśnych lub pozbawionych lasu. Ponieważ środowiskowe i społeczne koszty wycinania lasów sa bardzo wysokie, za pożąane uznaje się przede wszystkim wykorzystywania do tych celów terenów wylesionych. Organizacje konsumenckie staraja się wywierać wpływ na producentów żywności i biopaliw, aby wykorzystywali oni wyłacznie olej palmowy wyprodukowany zgodnie $z$ zasadą zrównoważonego rozwoju. Rozróżnienie szkodliwych dla środowiska od przyjaznych sposobów uprawy czę- sto jest jednak trudne (GAVEAU i współaut. 2016).

Odpowiedzia na te problemy było stworzenie kilku systemów certyfikacji upraw tej rośliny. Najważniejszym $z$ nich jest RSPO (ang. The Roundtable on Sustainable Palm Oil), czyli okragły stół zrównoważonego wytwarzania oleju palmowego. Tworzy go grupa składająca się $z$ producentów oleju palmowego, przedsiębiorstw zajmujących się jego przetwórstwem i sprzedaża oraz różnych agencji rzadowych i organizacji pozarząowych. RSPO wyznacza kryteria i określa zasady najlepszych praktyk zrównoważonej produkcji oleju palmowego. System certyfikacji wymaga od producentów przestrzegania kilku zasad, m.in. przejrzystości systemu zarządzania, ochrony zasobów naturalnych oraz przeprowadzania oceny skutków społecznych i środowiskowych tej działalności. Szacuje się, że aktualnie certyfikowanych jest 3,5 mln ha plantacji, które łacznie generuja 21\% światowej produkcji oleju palmowego (VIJAY i współaut. 2016).

Oprócz systemu certyfikacji, powstało także wiele innych regulacji, które maja na celu zatrzymanie procesu wylesień i przekształcania obszarów bagiennych. Niektórzy producenci podejmuja zobowiazanie „zero-wylesień", aby uspokoić obawy konsumentów i odpowiedzieć na restrykcje wprowadzone m.in. w Europie. Niestety, do tej pory nie opracowano jednak jednoznacznych definicji, które precyzowałyby praktyczne znaczenie tego zobowiąania (GAVEAU i współaut. 2016).

$\mathrm{W}$ Indonezji obowiazuje moratorium zakazujace przekształcania na plantacje mokradel i lasów pierwotnych (Instrukcja Prezydenta Indonezji nr 6/2013). Dekret prezydenta tego kraju (nr 32/1990) zabrania też zakładania upraw rolniczych na torfach o głębokości $3 \mathrm{~m}$ i większej (AFRIYANTI i współaut. 2016). Istnieją również regulacje europejskie, np. Dyrektywa Parlamentu Europejskiego i Rady Europejskiej 2009/28/WE w sprawie promowania stosowania energii ze źródeł odnawialnych, która zakazuje przekształcania pod produkcje biopaliw terenów podmokłych oraz obszarów zalesionych. Rozporzadzenie Parlamentu Europejskiego i Rady Europejskiej (1169/2011) nakazuje również oznakowanie produktów spożywczych zawierających olej palmowy.

\section{CHARAKTERYSTYKA OLEJU PALMOWEGO}

Z owoców olejowca gwinejskiego (palmy olejowej) otrzymuje się dwa rodzaje oleju: olej $z$ nasion palmowych i olej $z$ miąższu, powszechnie nazywany olejem palmowym 


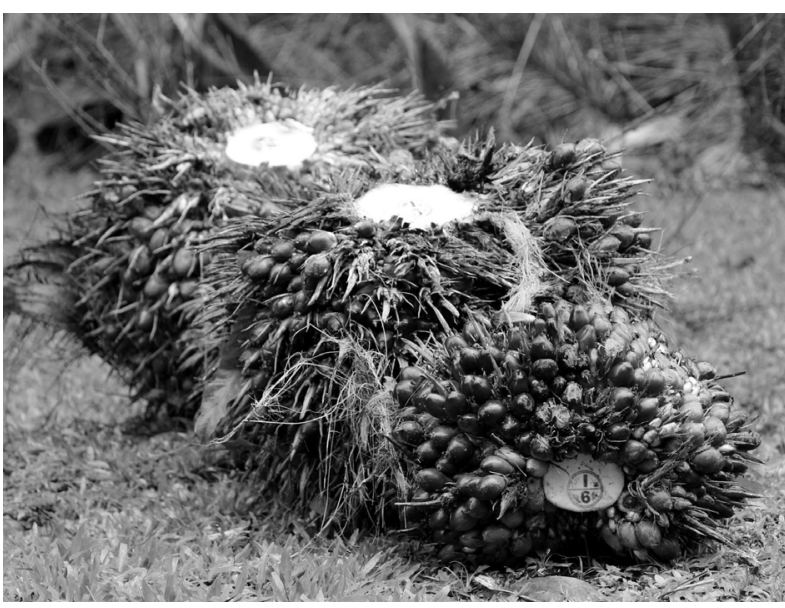

Ryc. 6. Owocostany olejowca gwinejskiego; olej palmowy pozyskuje się $z$ nasion i $z$ miąższu owoców (fot. A. Węgiel).

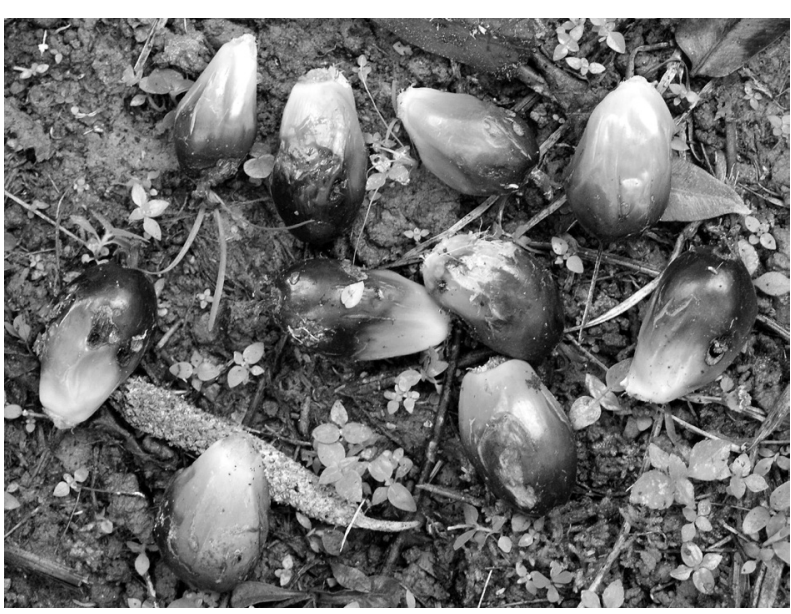

Ryc. 7. Owoce olejowca gwinejskiego - pestkowce, wewnątrz których znajduja się nasiona (fot. B. Wiatrowska).

(MANCINI i współaut. 2015). Olej z nasion palmy olejowej produkowany jest na niewielką skalę przez tłoczenie wysuszonych i zmielonych nasion, oddzielonych od tłuszczowej owocni. Olej ten ma jasną barwę i przypomina olej kokosowy. Z kolei olej palmowy, powstaje $\mathrm{w}$ wyniku działania para wodna na całe owocostany (Ryc. 6-7) palmy olejowej (KowALSKA i współaut. 2012).

Olej palmowy i olej $z$ nasion palmy charakteryzuja się odmiennym składem, który $z$ kolei determinuje właściwości technologiczne i żywieniowe tych surowców. W odniesieniu do składu, różnice pomiędzy nimi dotycza przede wszystkim profilu kwasów tłuszczowych (Ryc. 8) i zawartości związków bioaktywnych. W oleju $z$ nasion palmy dominuja nasycone kwasy thuszczowe (NKT), stanowiace aż 85\% ogólnej zawartości kwasów tłuszczowych tego surowca. Sa to przede wszyst-
A

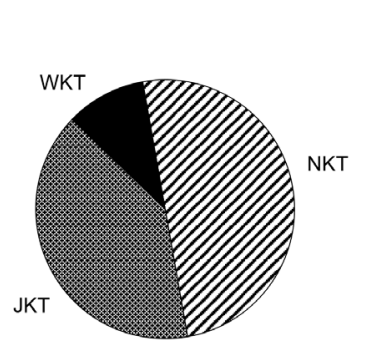

B

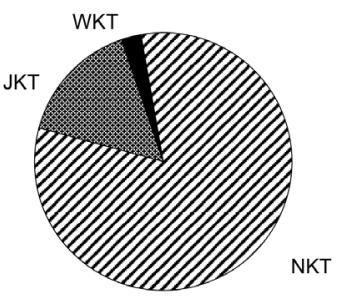

Ryc. 8. Procentowy skład kwasów tłuszczowych w oleju palmowym (A) i oleju $z$ nasion palmowych (B). NKT - nasycone kwasy tłuszczowe; JKT jednonienasycone kway tłuszczowe; WKT - wielonienasycone kwasy thuszczowe (na podstawie: KOWALSKA i współaut. 2012, MANCINI i współaut. 2015).

kim kwasy laurynowy i mirystynowy. Olej palmowy odznacza się natomiast 50\% udzialem NKT, kolejne $40 \%$ stanowia jednonienasycone kwasy thuszczowe (JKT), a pozostałe $10 \%$ to wielonienasycone kwasy thuszczowe (WKT). Spośród NKT w największej ilości występuje kwas palmitynowy (44\% ogólnej puli kwasów tłuszczowych), a w mniejszej kwas stearynowy (5\%); wśród JKT identyfikuje się kwas oleinowy, a dominujacym ilościowo zwiazkiem $z$ grupy WKT jest kwas linolowy, należący do rodziny n-6 (MANCINI i współaut. 2015).

Surowy olej palmowy, znany również jako czerwony olej palmowy, jest najbogatszym naturalnym żródłem karotenoidów (500-700 ppm) i jednym $z$ najbogatszych źródeł witaminy E (600-1200 ppm) (MBA i współaut. 2015). Zawiera ponadto fitosterole, skwalen, koenzym $\mathrm{Q}$ oraz witamine $\mathrm{K}$, fosfolipidy, flawonoidy.

Spośród karotenoidów w czerwonym oleju palmowym obecnych jest aż 13 związków, sa to: fitoen, fitofluen, cis- $\beta$-karoten, $\beta$-karoten, $\quad \alpha$-karoten, cis- $\alpha$-karoten, $\zeta$-karoten, $\gamma$-karoten, $\delta$-karoten, neurosporen, $\beta$-zeakaroten, a-zeakaroten i likopen. W ogólnej puli tych związków aż 65\% stanowi $\beta$-karoten, kolejne $33 \%$ a-karoten, a pozostałe zwiazki to jedynie $2 \%$. To właśnie karotenoidy nadaja czerwona barwę surowego oleju palmowego (KowALSKA i współaut. 2012, MвA i współaut. 2015). Tokochromanole obecne w czerwonym oleju palmowym reprezentowane sa zarówno przez tokoferole (a-T, $\beta-\mathrm{T}, \gamma-\mathrm{T}, \delta-\mathrm{T}$ ), jak i tokotrienole (a-T-3, $\beta-\mathrm{T}-3, \gamma-\mathrm{T}-3, \delta-\mathrm{T}-3)$. Te ostatnie występuja w przewadze (78-82\% ogólnej puli tokochromanoli), co jest unikatowa cechą oleju palmowego $\mathrm{w}$ porównaniu do innych olejôw roślinnych (NOGALA-KAEUCKA i SIgER 2011, KOWALSKA i współaut. 2012, MBA i współaut. 2015). 
Karotenoidy, tokoferole i tokotrienole (witamina E), ze względu na działanie antyoksydacyjne, odpowiadają za wysoka stabilność oksydacyjna czerwonego oleju palmowego. Zwiazki te wykazuja działanie antyoksydacyjne również w organizmie człowieka. Co więcej, tokoferole i tokotrienole wpływaja korzystnie na profil lipidowy, wykazuja działanie przeciwmiażdżycowe, przeciwnowotworowe, przeciwzapalne, antyproliferacyjne, antyagregacyjne oraz proapoptyczne. Karotenoidy $z$ kolei sa prekursorami witaminy A, która jest niezbędna $w$ procesie widzenia, uczestniczy w procesach wzrostu i różnicowania komórek (MBA i współaut. 2015). Należy mieć jednak świadomość, że surowy (czerwony) olej palmowy, nim stanie się składnikiem produktów spożywczych, poddawany jest wielu procesom technologicznym wpływającym na jego skład, przydatność przetwórczą i wartość odżywczą.

\section{W JAKIEJ FORMIE TŁUSZCZ PALMOWY WYSTEPUJE W ŻYWNOŚCI?}

Surowy (czerwony) olej palmowy zawiera szereg związków postrzeganych jako pożądane $z$ żywieniowego punktu widzenia i wpływających korzystnie na stabilność oksydacyjna samego surowca (tokoferole, tokotrienole, karotenoidy, fitosterole). Jednakże, obok składników aktywnych biologicznie, w czerwonym oleju palmowym obecne sa również związi wpływające negatywnie na stabilność przechowalniczą, przydatność przetwórcza oraz cechy sensoryczne surowca. Zalicza się do nich wolne kwasy tłuszczowe, fosfolipidy, śluzy oraz produkty utleniania tłuszczów (MANCINI i współaut. 2015, MBA i współaut. 2015). Przemysł spożywczy stawia tłuszczom i olejom wykorzystywanym w produkcji i przetwórstwie żywności konkretne wymagania; surowce te powinny być bez smaku, bez zapachu i odznaczać się jasna barwą. Stąd, majac na uwadze wykorzystanie oleju palmowego na cele spożywcze, istnieje konieczność poddawania czerwonego oleju palmowego procesowi rafinacji (MANCINI i współaut. 2015). Celem rafinacji jest oczyszczenie oleju, nadanie mu prawidłowych właściwości organoleptycznych i przedłużenie jego trwałości. Przebieg procesu rafinacji przedstawiono na Ryc. 9.

W dalszych etapach rafinowany olej palmowy może być poddawany procesom modyfikacji, w tym uwodornieniu, przeestryfikowaniu i frakcjonowaniu. Uwodornienie polega na przyłączeniu atomów wodoru do podwójnych wiazań w cząsteczkach nienasyconych kwasów tłuszczowych. Proces prowadzi się w temperaturze do $200^{\circ} \mathrm{C}$, pod zwiększonym ciśnieniem i w obecności katalizatora.

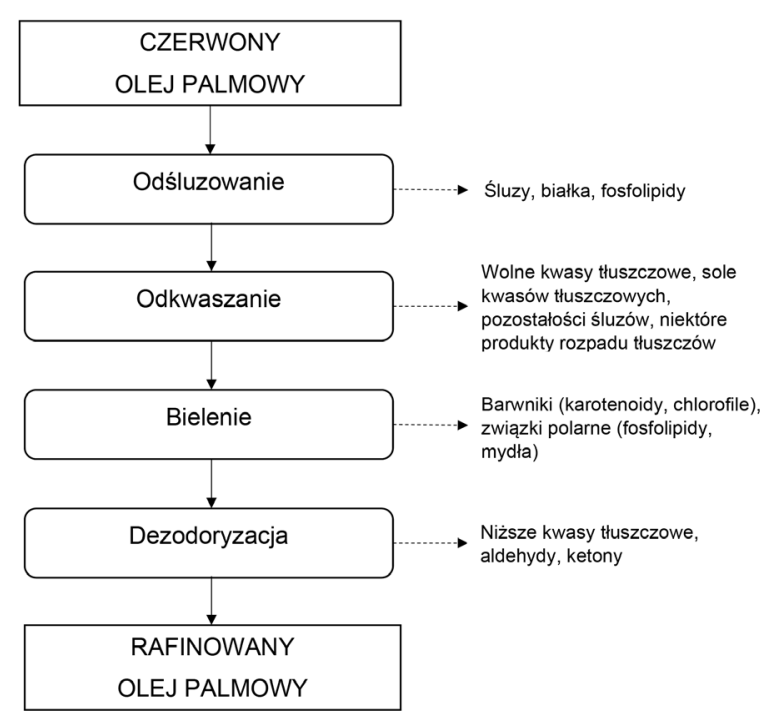

Ryc. 9. Przebieg procesu rafinacji czerwonego oleju palmowego (na podstawie: FLACZYK i współaut. 2006, MBA i współaut. 2015).

Produktem końcowym sa tłuszcze o konsystencji stałej w temperaturze pokojowej, tzw. tłuszcze utwardzone, lub tłuszcze o podwyższonej odporności na utlenianie, oleje częściowo utwardzone. $Z$ żywieniowego punktu widzenia proces uwodornienia wywołuje wiele niekorzystnych zmian w tłuszczach, w tym: wzrost zawartości nasyconych kwasów tłuszczowych, zmiany izomeryzacyjne - powstaja izomery trans nienasyconych kwasów tłuszczowych, częściowa polimeryzację kwasów tłuszczowych, cyklizację oraz hydrolizę. Alternatywę dla procesu uwodornienia stanowi przeestryfikowanie (transestryfikacja, interestryfikacja). Pod nazwa ta kryje się grupa spokrewnionych reakcji polegajacych na wymianie kwasów tłuszczowych związanych estrowo $z$ glicerolem w cząsteczce triacyloglicerolu (w cząsteczce triacyloglicerolu kwasy tłuszczowe moga występować w trzech pozycjach: $s n-1, s n-2$ i $s n-3)$. Reakcje przeestryfikowania prowadzone sa w odpowiednich warunkach temperatury i ciśnienia, w obecności katalizatora w sposób kierowany lub niekierowany. Istnieje też możliwość prowadzenia reakcji przeestryfikowania $z$ wykorzystaniem enzymów (przeestryfikowanie enzymatyczne). Co istotne, reakcje przeestryfikowania nie wpływaja na budowę łańcuchów kwasów tłuszczowych (m.in. nie powstaja izomery trans nienasyconych kwasów tłuszczowych), a modyfikujac strukturę triacylogliceroli (zmiana rozkładu czassteczek kwasów tłuszczowych w pozycjach sn-1, sn-2 i ns-3 glicerolu), oddziałuja na właściwości tłuszczów: temperaturę topnienia, formę krystaliczną i zawartość fazy stałej. W wyni- 
ku reakcji przeestryfikowania możliwa jest $\mathrm{m}$.in. przemiana olejów roślinnych $\mathrm{w}$ półstaly thuszcz bez uwodronienia; surowiec taki może być wykorzystywany do produkcji wysokiej jakości margaryn (o niskiej zawartości izomerów trans). Procesy przeestryfikowania wykorzystuje się także do produkcji preparatów zawierajacych średniołańcuchowe kwasy tłuszczowe (łatwiej przyswajalne), namiastek masła kakaowego $z$ innych tłuszczów roślinnych (naturalnych i uwodornionych), czy wyrobów tłuszczowych o podwyższonych właściwościach żywieniowych (w pozycji sn-2 czasteczki triacyloglicerolu wprowadza się kwasy $z$ rodziny n-3) (FLACZYK i współaut. 2006). Powszechnie prowadzonym procesem modyfikacji oleju palmowego jest też frakcjonowanie. Pozwala ono na otrzymanie $z$ oleju palmowego dwóch frakcji: oleiny palmowej (frakcja płynna) i stearyny palmowej (frakcja stała) (MBA i współaut. 2015).

Czerwony olej palmowy dostępny jest na rynku w postaci produktu jednoskładnikowego: czystego czerwonego oleju lub suplementów diety. Olej palmowy występujacy $\mathrm{w}$ produktach spożywczych wieloskładnikowych to olej palmowy rafinowany lub olej palmowy częściowo/całkowicie utwardzony. Zgodnie z Rozporzadzeniem Parlamentu Europejskiego i Rady (UE) w sprawie przekazywania konsumentom informacji na temat żywności (nr 1169/2011), w przypadku, gdy $\mathrm{w}$ produkcie zawarty jest olej lub tłuszcz uwodorniony, niezależnie od pochodzenia (roślinny lub zwierzęcy), jego oznaczeniu w wykazie składników musi towarzyszyć określenie "całkowicie uwodorniony/utwardzony" lub „częściowo uwodorniony/utwardzony”. Informacja ta jest istotna dla konsumenta, gdyż pośrednio wskazuje, że dany produkt może być źródłem izomerów trans nienasyconych kwasów tłuszczowych (dotyczy jedynie oleju częściowo uwodornionego). O ile nie budzi jakichkolwiek watpliwość kwestia, iż przyjmowanie $z$ dieta izomerów trans nienasyconych kwasów tłuszczowych wywiera negatywny wpływ na stan zdrowia człowieka, o tyle wpływ spożywania rafinowanego i całkowicie uwodornionego oleju palmowego na zdrowie ludzi pozostaje $\mathrm{w}$ dalszym ciagu nie do końca wyjaśniony.

\section{CZY TŁUSZCZ PALMOWY JEST NAM NIEZBEDNY?}

Problem wpływu spożywania oleju palmowego na zdrowie człowieka omawiany jest najczęściej w kontekście efektów metabolicznych nasyconych kwasów tłuszczowych oraz izomerów trans nienasyconych kwasów tłuszczowych.
Jak już wspomniano, olej palmowy charakteryzuje się dużym udziałem nasyconych kwasów tłuszczowych (około 50\%). Kwasy te wywieraja działanie hipercholesterolemiczne i proagregacyjne, zwiększając ryzyko zakrzepów naczyniowych. Do nasyconych kwasów tłuszczowych o najsilniejszym działaniu aterogennym (miażdzycorodnym) należą kwasy: laurynowy (12:0), mirystynowy (14:0) i palmitynowy (16:0) (WOLAN̂SKA i KŁOSIEWICZ-LatoszeK 2012). Ostatni $z$ wymienionych stanowi około 44\% ogólnej puli kwasów tłuszczowych oleju palmowego. Olej palmowy charakteryzuje się zawartościa nasyconych kwasów tłuszczowych zbliżoną do ich zawartości w tłuszczach zwierzęcych. Niektórzy autorzy zwracaja jednak uwagę, na zróżnicowanie rozkładu kwasów tłuszczowych w cząsteczkach triacylogliceroli (pozycje $s n-1$, $s n-2, s n-3)$ w oleju palmowym w porównaniu triacylogliceroli tłuszczów zwierzęcych. Okazuje się bowiem, że około $70 \%$ kwasu palmitynowego obecnego $\mathrm{w}$ oleju palmowym znajduje się $\mathrm{w}$ pozycjach $s n-1$ i $s n-3$ triacylogliceroli, podczas gdy $\mathrm{w}$ tłuszczach zwierzęcych większość tego kwasu znajduje się w pozycji sn-2 (Sun i współaut. 2015). Uczestnicząca $\mathrm{w}$ trawieniu tłuszczów lipaza, wykazuje silna specyficzność wobec pozycji sn-1 i $s n-3$ triacylogliceroli, katalizuje więc powstawanie $s n-2$ monoacylogliceroli oraz wolnych kwasów tłuszczowych. Sn-2 monoacyloglicerole podlegaja acydolizie $\mathrm{i}$ sa transportowane przez chylomikrony. Kwasy tłuszczowe uwolnione $z$ pozycji $s n-1$ i $s n-3$ moga być wchłanianie na drodze innych, mniej efektywnych szlaków metabolicznych (WIRKOWSKA i współaut. 2012). W zwiazku ze skuteczniejszym wchłanianiem kwasów tłuszczowych $z$ pozycji sn-2, sugeruje się, że działanie hipercholesterolemiczne $i$ aterogenne oleju palmowego (kwas palmitynowy wbudowany głównie $\mathrm{w}$ pozycje $s n-1$ i $s n-3$ triacylogliceroli) może być niższe niż tłuszczów pochodzenia zwierzęcego (EBONG i współaut. 1999).

Jednym $z$ argumentów przemawiającym za stosowaniem oleju palmowego $w$ przemyśle spożywczym był fakt, że surowiec ten miał stanowić alternatywę dla częściowo uwodornionych olejów roślinnych, zawierających znaczne ilości izomerów trans. Ze względu na swa naturalnie półstała konsystencję $\mathrm{w}$ temperaturze pokojowej, olej palmowy miał znaleźć zastosowanie do produkcji wysokiej jakości margaryn i tłuszczów, wykorzystywanych w różnych gałęziach przemysłu spożywczego. Powstające w trakcie procesu częściowego uwodornienia olejów roślinnych, izomery trans nienasyconych kwasów tłuszczowych wykazują negatywny wpływ na zdrowie człowieka, w tym: przez wpływ na zmiany profilu lipidowego, przy- 
czyniaja się do zwiększenia ryzyka chorób układu sercowo-naczyniowego; zmniejszając elastyczność i płynność błon komórkowych wpływają na aktywność receptorów i enzymów błonowych, prowadzac do zaburzeń funkcjonowania komórek organizmu; ich nadmierne spożycie zwiazane jest ze wzrostem ryzyka cukrzycy typu 2 i niektórych nowotworów; wpływaja niekorzystnie na rozwój układu nerwowego u niemowląt i dzieci (Cichosz i CzECzOT 2012). Zdaje się jednak, że mimo szerokiego stosowania oleju palmowego w przemyśle spożywczym, problem obecności izomerów trans nienasyconych kwasów tłuszczowych nie został całkowicie wyeliminowany, co więcej, sam olej palmowy poddawany jest procesom modyfikacji, w tym uwodornieniu. Przykładowo, PAszcZYK i ŁUCZYŃSKA (2013) notowały, że izomery trans nienasyconych kwasów tłuszczowych stanowiły od $0,27 \%$ do $26,63 \%$ z ogólnej puli tłuszczu w dostępnych na polskim rynku margarynach twardych oraz od 0,33\% do $15,46 \%$ w margarynach miękkich. Z kolei, ich zawartość w wybranych ciastach dostępnych na olsztyńskim rynku wynosiła od 0,01 g/100g do 3,65 g/100 g (PASZCZYK i współaut. 2009). Co więcej, w składzie wielu oferowanych obecnie na rynku produktów spożywczych znajduje się częściowo utwardzony tłuszcz palmowy.

Ciekawe porównanie wpływu spożywania rafinowanego oleju palmowego i olejów o odmiennym składzie kwasów tłuszczowych, na profil lipidowy krwi stanowi meta-analiza badań klinicznych $z$ udziałem ludzi, przeprowadzona przez Sun i współaut. (2015). W analizie tej uwzględniono porównanie wpływu spożywania rafinowanego oleju palmowego $z$ (i) olejami roślinnymi ubogimi w nasycone kwasy tłuszczowe, (ii) tłuszczami częściowo uwodornionymi, zawierajacymi izomery trans nienasyconych kwasów tłuszczowych oraz (iii) tłuszczami zwierzecymi, bogatymi w nasycone kwasy thuszczowe, na wybrane parametry profilu lipidowego krwi. W odniesieniu do pierwszego $z$ porównań odnotowano, że spożywanie oleju palmowego wiązało się ze wzrostem stężenia we krwi całkowitego cholesterolu, wzrostem stężenia cholesterolu frakcji LDL (tzw. „zły” cholesterol) oraz niewielkim $z$ punktu widzenia klinicznego (ale istotnym statystycznie) wzrostem stężenia cholesterolu frakcji HDL (tzw. "dobry" cholesterol). Nie odnotowano natomiast różnic w stężeniu triacylogliceroli we krwi. Drugie $z$ wymienionych porównań wykazało, że spożywanie oleju palmowego było zwiazane ze wzrostem stężenia cholesterolu HDL, natomiast nie obserwowano wpływu na stężenie cholesterolu całkowitego, cholesterolu frakcji LDL oraz triacylogliceroli.
Trzecie $z$ przeprowadzonych porównań (olej palmowy $v s$ tłuszcze zwierzęce), obejmowało zaledwie dwa badania przeprowadzone w grupach mężczyzn o prawidłowym stężeniu cholesterolu w surowicy krwi, reprezentujących populacje krajów zachodnich. Porównanie to nie ujawniło zróżnicowanego wpływu spożywania dwóch analizowanych grup tłuszczów na profil lipidowy krwi. Omawiana metaanaliza ukazuje, że przy ocenie wpływu spożywania rafinowanego oleju palmowego na profil lipidowy krwi u ludzi, istotne znaczenie ma fakt, jakiego produktu substytutem ma być olej palmowy lub jaki substytut zostanie wprowadzony do diety w miejsce oleju palmowego. Jednocześnie wyniki pracy SuN i współaut. (2015) nie potwierdzaja koncepcji niższej aterogenności rafinowanego oleju palmowego niż tłuszcze zwierzęce o zbliżonej zawartości nasyconych kwasów tłuszczowych.

W ostatnich latach podnoszona jest kwestia bezpieczeństwa stosowania rafinowanego oleju palmowego w kontekście obecności w nim estrów kwasów tłuszczowych z 3-monochloropropan-1,2-diolem (3-MCPD) i estrów kwasów tłuszczowych glicydolu (GE). Zwiąki te powstaja w oleju palmowym i w innych olejach roślinnych, w trakcie procesu rafinacji - zwłaszcza na etapie dezodoryzacji (m.in. za sprawa działania wysokiej temperatury). Wśród rafinowanych olejów roślinnych największe ilości GE i estrów 3-MCDP stwierdza się w olejach palmowym, kukurydzianym i kokosowym, a najmniejsze w oleju rzepakowym. Obecność estrów 3-MCDP stwierdzano także w innych produktach spożywczych poddawanych obróbce w wysokich temperaturach, m.in. w: produktach zbożowych, prażonej kawie, rybach wędzonych, produktach mięsnych, mlecznych, a także w sosach na bazie białek roślinnych otrzymywanych na drodze hydrolizy kwasowej (np. w sosie sojowym). Estry 3-MCDP i GE w odpowiednich warunkach, np. pod wpływem działania enzymów przewodu pokarmowego, moga ulegać deestryfikacji $Z$ wytworzeniem wolnego glicydolu i 3-MCDP. Glicydiol i 3-MCDP zostały zaliczone przez Międzynarodową Agencję Badań nad Rakiem do karcynogenów odpowiednio grupy 2A (czynnik prawdopodobnie rakotwórczy dla ludzi) i 2B (czynnik przypuszczalnie rakotwórczy dla ludzi) (ANIOŁOWSKA i KITA 2014). Dla porównania, przetworzone produkty mięsne zostały przez tę instytucje zaliczone do karcynogenów grupy 1 (czynniki rakotwórcze dla ludzi).

Warto również rozważyć niezbędność oleju palmowego $z$ punktu widzenia zaspakajania potrzeb żywieniowych. Czerwony olej palmowy może stanowić znaczace źródło 
tokoferoli i karotenoidów, ale zwiazki te zawarte sa także $\mathrm{w}$ wielu innych powszechnie dostępnych produktach spożywczych. Rafinowany olej palmowy nie może być uznany za źródło tokoferoli i karotenoidów, niewatpliwe jest natomiast źródłem nasyconych kwasów tłuszczowych. Organizm ludzki jest $\mathrm{w}$ stanie syntetyzować nasycone kwasy tłuszczowe, więc nie ma konieczności ich dostarczania $z$ pożywieniem. Produkty zawierające częściowo uwodorniony olej palmowy sa źródłem izomerów trans nienasyconych kwasów tłuszczowych, co do których nie ma watpliwości, że wywieraja negatywny wpływ na zdrowie człowieka. Warto również wspomnieć, że rafinowany olej palmowy oraz częściowo i całkowicie utwardzony tłuszcz palmowy są często składnikami żywności wysoko przetworzonej: wyrobów cukierniczych i czekoladowych, słonych przekasek, zup i dań typu instant. Sa to produkty charakteryzujące się nie tylko niekorzystnym profilem kwasów tłuszczowych, ale często wysoka gęstością energetyczna oraz duża zawartościa cukrów prostych i soli. Z punktu widzenia profilaktyki większości chorób dietozależnych produkty takie nie sa zalecane $\mathrm{w}$ diecie człowieka.

\section{PROGNOZY NA PRZYSZŁOŚĆ}

Wydaje się, że ekspansja plantacji olejowca gwinejskiego $\mathrm{w}$ nadchodzacych dekadach jest nieunikniona, bowiem ze wzgle-du na rosnącą liczbę ludności, tylko olej palmowy ma potencjał do sprostania coraz wyższemu zapotrzebowaniu na żywność i energię. Obecnie największymi jego importerami sa kraje o największej liczbie ludności, czyli Indie i Chiny (TAN i współaut. 2009). Negatywny wpływ plantacji na środowisko będzie jeszcze większy, gdy zaczną się one rozprzestrzeniać na inne regiony o wysokiej różnorodności biologicznej, czyli obszary tropikalne Afryki i Ameryki Południowej (GIAM i współaut. 2016).

Jedna $z$ odpowiedzi na problemy ekspansji rolnictwa sa próby zwiększenia wydajności roślin uprawnych. Zwiększenie produktywności pozwoliłoby bowiem na zaspokojenie globalnego zapotrzebowania na produkty rolne, bez potrzeby zwiększania powierzchni upraw. Obecnie modyfikacje genetyczne roślin wytwarzających takie produkty jak: olej, biomasa, kauczuk, soja, ryż czy kakao pozwalaja już na znaczny wzrost ich plonów. Zwiększenie wydajności plantacji olejowca gwinejskiego, mogłoby ograniczyć ich ekspansje na nowe tereny. Spodziewany jest jednak dalszy, wręcz lawinowy wzrost popytu na olej palmowy w perspektywie do 2050 r. Wprawdzie, podniesienie produkcyjności z
4 do 5,2 ton/ha pozwoliłoby na zachowanie $7 \mathrm{mln}$ ha lasów $(7 \%$ powierzchni lasów w Indonezji), ale taki wzrost wydajności nie wystarczy na pokrycie szybko rosnacego zapotrzebowania, które może być jeszcze większe, gdy olejem palmowym będa zastępowane inne oleje roślinne (CARRASCO i współaut. 2014).

Aby ograniczyć negatywny wpływ na środowisko, zakładanie nowych plantacji dostarczajacych oleju palmowego powinno odbywać się więc przede wszystkim na gruntach zdegradowanych, pozbawionych lasu (WICKE i współaut. 2008). Dostępność tego typu terenów, nadających się do założenia plantacji, jest na tyle duża, że pozwoliłaby znaczaco zwiększyć produkcję oleju bez konieczności dalszych wylesien. Niestety, bezwładność polityczna oraz wysokie zapotrzebowanie na drewno i olej palmowy, często sprawiaja, że najtańszym i najłatwiejszym rozwiazaniem jest wyrą lasów (FITZHERBERT i współaut. 2008).

Tam gdzie nie jest to wymagane (poza UE i USA), producenci żywności niechętnie podaja w składzie obecność oleju palmowego, bo wielu konsumentów ma świadomość, że jest on zwiazany $\mathrm{z}$ chorobami układu krażenia i problemami środowiskowymi. Z tego powodu, nawet ci wytwórcy, którzy stosuja przyjazne dla środowiska certyfikowane uprawy, nie umieszczaja tych informacji na produktach. Żeby spowodować większe zapotrzebowanie na certyfikowane produkty, należy zwiększyć świadomość społeczna w tym zakresie (GiAM i współaut. 2016). Ważnym czynnikiem, który może wpłynąć na ograniczenie ekspansji plantacji są więc decyzje konsumentów. Wybierając produkty nie zawierajace oleju palmowego, konsumenci moga bowiem kształtować popyt i wpływać na zmniejszenie zapotrzebowana na ten surowiec.

$$
\text { Streszczenie }
$$

W ostatnich dziesięcioleciach obserwowany jest znaczacy wzrost produkcji oleju palmowego, szeroko wykorzystywanego w wielu gałęziach przemysłu, w tym: spożywczym, kosmetycznym i energetycznym. Surowiec ten pozyskiwany jest $z$ owoców olejowca gwinejskiego (Elaeis guineensis Jacq.), którego plantacje zakładane sa głównie na obszarach tropikalnych Azji Południowo-Wschodniej. W kolejnych latach prognozowany jest dalszy wzrost zapotrzebowania na olej palmowy. Tymczasem niejasny pozostaje wpływ plantacji olejowca gwinejskiego na środowisko naturalne, w tym m.in. na wylesianie obszarów tropikalnych i różnorodność biologiczną oraz spożywania oleju palmowego na zdrowie człowieka. W pracy podjęto zatem próbę kompleksowego omówienia wymienionych problemów. Ostateczna ocena oddziaływania produkcji olejowca gwinejskiego jest złożona, gdyż musi uwzględniać, nie tylko aspekty środowiskowe, ale i kwestie etyczne (jak globalny wzrost zapotrzebowania na żywność, czy zapewnienie źródeł utrzymania lokalnej 
społeczności). Natomiast rozpatrując wpływ spożywania oleju palmowego na zdrowie człowieka, należy wziąć uwagę, m.in. różnice w składzie i wartości odżywczej surowego, rafinowanego i poddanego procesom modyfikacji oleju palmowego.

\section{LITERATURA}

AChard F., Eva H. D., Stibig H. J., Mayaux P., Gallego J., Richards T., Malingreau J. P., 2002. Determination of deforestation rates of the world's humid tropical forests. Science 297, 999-1002.

AFRIYANTI D., KROEZE C., SAAD A., 2016. Indonesia palm oil production without deforestation and peat conversion by 2050. Sci. Total Environ. 557 562-570.

ANIOEOWSKA M., KITA A., 2014. Estry kwasów tłuszczowych glicydolu oraz estry kwasów tłuszczowych mono-3-chloropropan-1,2-diolu nowe zanieczyszczenia $w$ olejach jadalnych. Wiad. Chem. 68, 701-717.

ARATRAKORN S., THUNHIKORN S., DONALD P. F., 2006. Changes in bird communities following conversion of lowland forest to oil palm and rubber plantations in southern Thailand. Bird Conserv. Intern. 16, 71-82.

BASIRON Y., 2007. Palm oil production through sustainable plantations. Eur. J. Lipid Sci. Technol. 109, 289-295.

BRÜHL C. A., ELTZ T., 2010. Fuelling the biodiversity crisis: species loss of ground-dwelling forest ants in oil palm plantations in Sabah, Malaysia (Borneo). Biodivers. Conserv. 19, 519-529.

Campbell-Smith G., Campbell-Smith M., SingleTON I., LINKIE M., 2011. Apes in space: saving an imperilled orangutan population in Sumatra. PLoS One 6, doi.org/10.1371/journal. pone.0017210.

Carrasco L. R., larrosa C., Milner-Gulland E. J., EDWARDS D. P., 2014. A double-edged sword for tropical forests. Science 346, 38-40.

Chung A. Y. C., EgGleton P., Speight M. R., HAMMOND P. M., CHEY V. K., 2000. The diversity of beetle assemblages in different habitat types in Sabah, Malaysia. Bull. Entomol. Res. 90, 475-496.

Cichosz G., CzECzOT H., 2012. Kwasy tłuszczowe izomerii trans $w$ diecie człowieka. Bromatologia i Chemia Toksykologiczna 45, 181-190.

Danielsen F., Beukema H., Burgess N. D., PARISH F., BRÜHL C. A., DONALD P. F., MURDIYARSo D., Phalan B., ReiJnders L., Struebig M., FITZHERBERT E. B., 2009. Biofuel plantations on forested lands: double jeopardy for biodiversity and climate. Conserv. Biol. 23, 348358.

DoNALD P. F., 2004. Biodiversity impacts of some agricultural commodity production systems. Conserv. Biol. 18, 17-37.

EBong P. E., OwU D. U., Isong E. U., 1999. Influence of palm oil (Elaesis guineensis) on health. Plant Foods Human Nutr. 53, 209222.

Edwards D. P., Hodgson J. A., Hamer K. C., MitCHEll S. L., AHMAD A. H., CORNEll S. J., WILCOVE D. S., 2010. Wildlife-friendly oil palm plantations fail to protect biodiversity effectively. Conserv. Lett. 3, 236-242.

EDWARDS F. A., EDWARDS D. P., SLOAN S., HAMER K. C., 2014. Sustainable management in crop monocultures: The impact of retaining forest on oil palm yield. PLoS One 9, doi.org/10.1371/ journal.pone.0091695 .
FARUK A., BElabut D., AHMAD N., KNEll R. J., GARNER T. W. J., 2013. Effects of oil-palm plantations on diversity of tropical anurans. Conserv. Biol. 27, 615-624.

Fayle T. M., Turner E. C., SNaddon J. L., Chey V. K., Chung A. Y. C., EgGleton P., Foster W. A., 2010. Oil palm expansion into rain forest greatly reduces ant biodiversity in canopy, epiphytes and leaf-litter. Basic Appl. Ecol. 11, 337-345.

Fischer J., LindenMAYeR D. B., 2007. Landscape modification and habitat fragmentation: a synthesis. Global Ecol. Biogeogr. 16, 265-280.

FitzHERBERT E. B., Struebig M. J., MOREL A., DANIElSEN F., BRUHL C. A., DONALD P. F., PHALAN B., 2008. How will oil palm expansion affect biodiversity? Trends Ecol. Evol. 23, 538-545.

FlaczyK E., KorczaK J., PIKUl J., 2006. Tłuszcze jadalne. [W:] Towaroznawstwo produktów spożywczych. FLACZYK E., GÓRECKA D., KORCZAK J. (red.). Wydawnictwo Akademii Rolniczej im. Augusta Cieszkowskiego w Poznaniu, Poznań, 184-220.

Gallmetzer N., Schulze C. H., 2015. Impact of oil palm agriculture on understory amphibians and reptiles: A Mesoamerican perspective. Global Ecol. Conserv. 4, 95-109.

Gaveau D. L. A., Sheil D., Husnayaen, Salim M. A., ArJasakusuma S., Ancrenaz M., Pacheco P., MEIJAARD E., 2016. Rapid conversions and avoided deforestation: examining four decades of industrial plantation expansion in Borneo. Scientific Reports 6, doi: 10.1038/srep32017.

Giam X., Mani L., KoH L. P., Tan H. T. W., 2016. Saving tropical forests by knowing what we consume. Conserv. Lett. 9, 267-274.

GROOM M. J., GRAY E. M., TOWNSEND P. A., 2008. Biofuels and biodiversity: Principles for creating better policies for biofuel production. Conserv. Biol. 22, 602-609.

Holway D. A., Lach L., SuAREZ A. V., Tsutsui N. D., CASE T. J., 2002. The causes and consequences of ant invasions. Ann. Rev. Ecol. Syst. 33, 181-233.

ICKES K., 2001. Hyper-abundance of native wild pigs (Sus scrofa) in a lowland dipterocarp rain forest of peninsular Malaysia. Biotropica 33, 682-690.

$\mathrm{KoH}$ L. P., 2008. Can oil palm plantations be made more hospitable for forest butterflies and birds? J. Appl. Ecol. 45, 1002-1009.

$\mathrm{KOH}$ L. P., Wilcove D. S., 2008. Is oil palm agriculture really destroying tropical biodiversity? Conserv. Lett. 1, 60-64.

Kowalska M., Aldewicz M., Mroczek E., Cichosz G., 2012. Olej palmowy - tańsza i zdrowsza alternatywa. Bromatologia i Chemia Toksykologiczna 45, 171-180.

LAURANCE W. F., 2007. Forest destruction in tropical Asia. Curr. Sci. 93, 1544-1550.

LuCEY J. M., HILL J. K., 2012. Spillover of insects from rain forest into adjacent oil palm plantations. Biotropica 44, 368-377.

Luskin M. S., POTTS M. D., 2011. Microclimate and habitat heterogeneity through the oil palm lifecycle. Basic Appl. Ecol. 12, 540-551.

Luskin M. S., ChristinA E. D., Kelley L. C., POTTS M. D., 2014. Modern hunting practices and wild meat trade in the oil palm plantation-dominated landscapes of Sumatra, Indonesia. Human Ecol. 42, 35-45.

Maddox T., PRIATNA D., Gemita E., Selampassy A., 2007. The conservation of tigers and other wildlife in oil palm plantations, Jambi Province, Sumatra, Indonesia (October 2007). ZSL 
Conserv. Rep. No. 7. The Zoological Society of London, London.

MANCini A., IMPERLINI E., NigRo E., MONTAGNESE C., DANIEle A., ORRÙ S., BUONO P., 2015. Biological and nutritional properties of palm oil and palmitic acid: effects on health. Molecules 20, 17339-17361.

Mba O. I., Dumont M. J., NGadi M., 2015. Palm oil: Processing, characterization and utilization in the food industry - A review. Food Biosci. $10,26-41$.

MUKHERJEe I., SOVACOOL B. K., 2014. Palm oilbased biofuels and sustainability in southeast Asia: A review of Indonesia, Malaysia, and Thailand. Renewable Sustain. Energy Rev. 37 1-12.

Myers N., Mittermeier R. A., Mittermeier C. G. DA FonseCA G. A. B., KENT J., 2000. Biodiversity hotspots for conservation priorities. Nature 403, 853-858.

NogAlA-KalUCKA M., Siger A., 2011. Tokochromanole - bioaktywne zwiazki roślin oleistych. Od biosyntezy do biomarkerów. Rośliny Oleiste $32,9-28$.

PASZCZYK B., ŁUCZYŃSKA J., 2013. Skład kwa sów tluszczowych $i$ izomerów trans $w$ margarynach twardych $i$ miekkkich. Bromatologia i Chemia Toksykologiczna 46, 234-240.

PASZCZYK B., BOREJSZKO Z., SZEWCZYK A., 2009. Skład kwasów tłuszczowych - z uwzględnieniem izomerów trans - $w$ wybranych ciastach. Żywność Nauka Technologia Jakość 2, 94102.

Pfeiffer M., TUCK H. C., LAY T. C., 2008. Ex ploring arboreal ant community composition and co-occurrence patterns in plantations of oil palm Elaeis guineensis in Borneo and Peninsular Malaysia. Ecography 31, 21-32.

SCHARLEMANN J. P. W., LAURANCE W. F., 2008. Environmental science - How green are biofuels? Science 319, 43-44.

SodHI N. S., KOH L. P., BROOK B. W. NG P. K. L., 2004. Southeast Asian biodiversity: an impending disaster. Trends Ecol. Evol. 19, 654660.

Struebig M. J., Kingston T., Zubaid A., MOHD-ADNAN A., Rossiter S. J., 2008. Conservation value of forest fragments to Palaeotropical bats. Biol. Conserv. 141, 2112-2126.

SumARGa E., Hein L., 2016. Benefits and costs of oil palm expansion in Central Kalimantan, Indonesia, under different policy scenarios. Reg. Environ. Change 16, 1011-1021.
Sun Y., NeElakantan N., Wu Y., LOte-OKe R., PAN A., VAN DAM R. M., 2015. Palm oil consumption Increases $L D L$ cholesterol compared with vegetable oils low in saturated fat in a meta-analysis of clinical trials. J. Nutrit. 145, 1549-1558.

TAN K. T., LEe K. T., Mohamed A. R., Bhatia S., 2009. Palm oil: Addressing issues and towards sustainable development. Renewable Sustain. Energy Rev. 13, 420-427.

TSUi K. M., FrYar S. C., HodgKISS I. J., Hyde K. D., POONYTH A. D., TAYLOR J. E., 1998. The effect of human disturbance on fungal diversity in the tropics. Fungal Divers. 1, 19-26.

TSUJINO R., YUMOTO T, KITAMURA S., DJAMALUDDIN I., DARNAEDI D., 2016. History of forest loss and degradation in Indonesia. Land Use Policy $57,335-347$.

TURner E. C., SNADdon J. L., FAYle T. M., FosTER W. A 2008. Oil palm research in con text: identifying the need for biodiversity assessment. PLoS One 3, doi: 10.1371/journal. pone.0001572.

VijaY V., Pimm S. L., Jenkins C. N., Smith S. J., 2016. The impacts of oil palm on recent deforestation and biodiversity loss. PLoS One 11, doi: 10.1371/journal.pone.0159668.

WiCKE B., DORNBURG V., JUNGinger M., FAAIJ A., 2008. Different palm oil production systems for energy purposes and their greenhouse gas implications. Biomass Bioenergy 32, 13221337.

Wilcove D. S., KoH L. P., 2010. Addressing the threats to biodiversity from oil-palm agriculture. Biodivers. Conserv. 19, 999-1007.

WIRKOWSKA M., BRYŚ J., GÓRSKA A., OSTROWSKA-LIZEGA E., ŻUBRŻYCKA K., 2012. Wzbogacanie tłuszczu mlecznego $w$ kwasy $n-3$ na drodze przeestryfikowania enzymatycznego. Bromatologia i Chemia Toksykologiczna 45, 699-704.

WOLANSKA D., KŁOSIEWICZ-LATOSZEK L., 2012. Struktura spożycia kwasów tłuszczowych a profil lipidowy $u$ osób $z$ nadwaga $i$ otyłościa. Roczniki Państwowego Zakładu Higieny 63, 155-162.

WoOD B. J., FEE C. G., 2003. A critical review of the development of rat control in Malaysian agriculture since the 1960s. Crop Protect. 22, 445-461.

Yue S., BROdIE J. F., ZiPKIN E. F., BERNARD H., 2015. Oil palm plantations fail to support mammal diversity. Ecol. Appl. 25, 2285-2292. 
KOSMOS Vol. 67, 3, 647-659, 2018

Andrzej Węgiel ${ }^{1}$, Paulina NowaczyK ${ }^{2}$, Angelika Śmidowicz², Blanka Wiatrowska ${ }^{3}$

${ }^{1}$ Department of Forest Management, ${ }^{2}$ Department of Hygiene and Human Nutrition, ${ }^{3}$ Department of Forest Botany, Poznan University of Life Sciences, 28 Wojska Polskiego Str., 60-637 Poznań, e-mail: wegiel@up.poznan.pl

PALM OIL PROPERTIES AND THE IMPACT OF THE OIL PALM (ELAEIS GUINEENSIS JACQ.) PLANTATION ON THE ENVIRONMENT

\section{Summary}

In the last decades, a significant increase in palm oil production has been observed. The oil is widely used in many industries, including food, cosmetics and energy industry. Palm oil is obtained from the fruits of oil palm plantations, located mainly in the tropical areas of Southeast Asia. Further growth in the demand for palm oil is anticipated in the future. Yet, the impact of the oil palm plantations on the environment (among others deforestation of tropical areas and biodiversity) and the consumption of palm oil on human health remain unclear. The paper attempts to discuss the aforementioned problems comprehensively. The assessment of overall effect of oil palm plantation is complicated. Not only environmental aspects, but also ethical issues (such as global food demand and community livelihoods) should be taken into consideration. Whereas, in the context of the impact of palm oil consumption on human health attention should be paid, among others, to differences in the composition and nutritional value of raw, refined and modified palm oil.

Key words: biodiversity, deforestation, rain forests, saturated fatty acids, trans fats 